\title{
Orthodontic Extrusion of the Upper Central Incisor: A Rare Case of Pulp Mummification
}

\author{
Extrusión Ortodóncica del Incisivo Central Superior: un Caso Raro de Momificación Pulpar
}

\author{
José Artur Cunha Pupo*; Ana Cláudia Rossi"; Alexandre Rodrigues Freire*; \\ Paulo Henrique Ferreira Caria** \& Felippe Bevilacqua Prado**
}

PUPO, J. A. C.; ROSSI, A. C.; FREIRE, A. R.; CARIA, P. H. F. \& PRADO, F. B. Orthodontic extrusion of the upper central incisor: A rare case of pulp mummification. Int. J. Odontostomat., 7(2):241-244, 2013.

ABSTRACT: Due to its anatomical positioning, the central upper incisors are the most affected teeth when related to trauma injuries in the craniofacial region, among with nose traumas. In childhood, traumatic injury is most often caused by bicycle accidents, sports, recreational activities or falls. The aim of this report is to describe a treatment for intrusion of the left maxillary central incisor and the subsequent complications in an 8-year-old boy. Also, the report emphasizes the importance of careful long-term follow-up monitoring intruded permanent teeth. Pulp tissue, as other tissues in the human body, tends to change with traumas. Some of those changes are natural while others occur as result of injuries to the dentin-pulp complex such as caries lesions, periodontal disease, calcifications, as in the present report, or restorative dental procedures. Normally conducted endodontic treatment must take place to obtain maximal results, but only after the re-stabilization of the tooth.

KEY WORDS: orthodontic extrusion, pulp calcification, tooth movement, tooth avulsion.

\section{INTRODUCTION}

Traumatic intrusion of permanent teeth is a rare injury and accounts for $3 \%$ of all traumatic injuries to the permanent dentition (Andreasen \& Pedersen, 1985). Serious damage to the tooth pulp and supporting structures occur due to the tooth misplacement into the alveolar process. Thus, the repair process after intrusion is complex (Andreasen et al., 2006a). Pulp necrosis, inflammatory root resorption, ankylosis, obliteration of the pulp canal, marginal bone loss, disturbance to the continued development of the root may occur as consequences of an intrusive luxation (Andreasen et al., 2006b; Andreasen, 1970).

Treatment and prognosis of intrusive luxations can vary depending on the age of the patient, type of dentition, stage of root development, time and severity of the trauma (Calasans-Maia et al., 2003).

Surgical repositioning has been performed as treatment for intrusive luxation of permanent mature teeth, but, this kind of surgical approach leaves the intruded tooth lacking supporting tissue (alveolar bone and periodontal ligament) and can cause an unpleasant aesthetic defect, ankylosis, pulp necrosis and formation of a periodontal pocket (Kokich et al., 1984).

Many authors have suggested that orthodontic forces can be used immediately aiming repositioning the intruded tooth with the attachment apparatus after trauma (Chaushu et al., 2004; Oulis et al., 1996; Taintor et al., 1977), reducing the incidence of others sequels and reducing the chances of ankylosis Orthodontic treatment renders a biological way of repositioning the tooth, furthermore, early endodontic treatment of the root canal prevents inflammatory resorption (Caliskan et al., 1997).

Thus, the aim of this report is to describe a treatment for intrusion of the left maxillary central incisor and the subsequent complications in an 8-year-old boy. Also, the report emphasizes the importance of careful long-term follow-up monitoring intruded permanent teeth.

\footnotetext{
* Lins Dental Association, Specialization Course in Orthodontics, Lins, Brazil.

* Department of Morphology, Anatomy area, Piracicaba Dental School, State University of Campinas - UNICAMP, Piracicaba, Brazil.
} 


\section{CASE REPORT}

A healthy 8-year-old boy was referred to the Private Dentistry Clinic, following traumatic injury to his teeth caused by a bicycle accident after 30 days. No previous dental trauma was reported, and there was no history of neurological complications. The medical history was unremarkable.

The extra oral examination revealed no injury. The intra-oral examination revealed a $2 / 3$ coronary intrusive luxation of the left maxillary central incisor (Tooth 21 according to the FDI World Dental Federation) (Fig. 1A). The intruded tooth showed no clinical mobility. There was no evidence of traumatic injury to any other teeth or alveolar structures.

Then, it was decided in order to reposition the intruded tooth 21 to place an orthodontic multibracketed removable device associated with elastic (spring) traction (Fig. 1B). To bring back the tooth to its original position, traction strength of 40 grams 16 was applied to the tooth for 50 days and the same device was kept during 30 days to hold the tooth in place with no force induction.

Subsequent examinations revealed no evidence of pulp vitality, but the endodontic treatment could not be done by the impossibility of the access to the pulp chamber until traction and stabilization were finished.

Orthodontic extrusion started 1 week after the traction and approximately $1 \mathrm{~mm}$ of extrusive orthodontic movement occurred. Six weeks after the start of treatment by orthodontic extrusion the location of the intruded left maxillary central incisor was restored to its original position before its displacement had occurred. Orthodontic treatment was continued in order to obtain sufficient retention and for other orthodontic problems.

After the extrusion treatment (witch took around 50 days), endodontic procedure took place, considering that the tooth was already in its physiological positioning. When reached the pulp chamber, no bleeding was noticed and the pulp was mummified (Fig. 2).

Careful follow-up examinations were performed every 3 months in order to observe the intruded left maxillary central incisor. After eighteen months of follow-up examinations, no problems were detected (Figs. 3A and 3B).

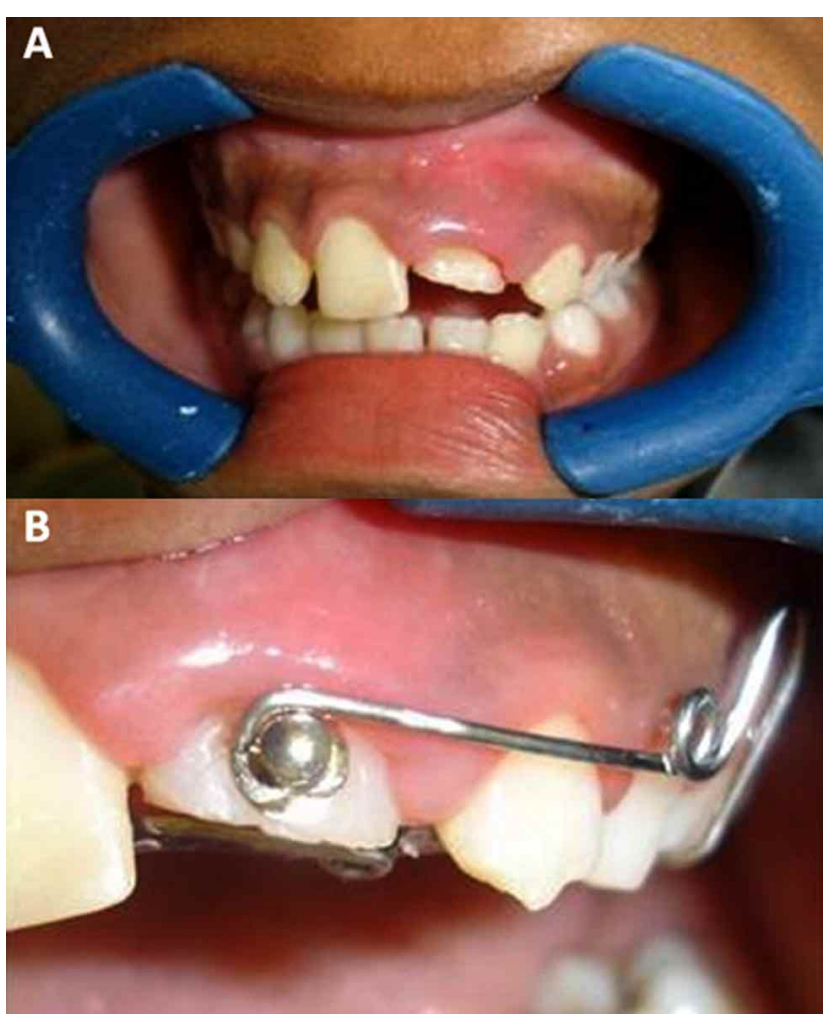

Fig. 1. A) Frontal view of the traumatically intruded tooth at the initial visit; B) Removable Orthodontic device associated to an extrusive coil.

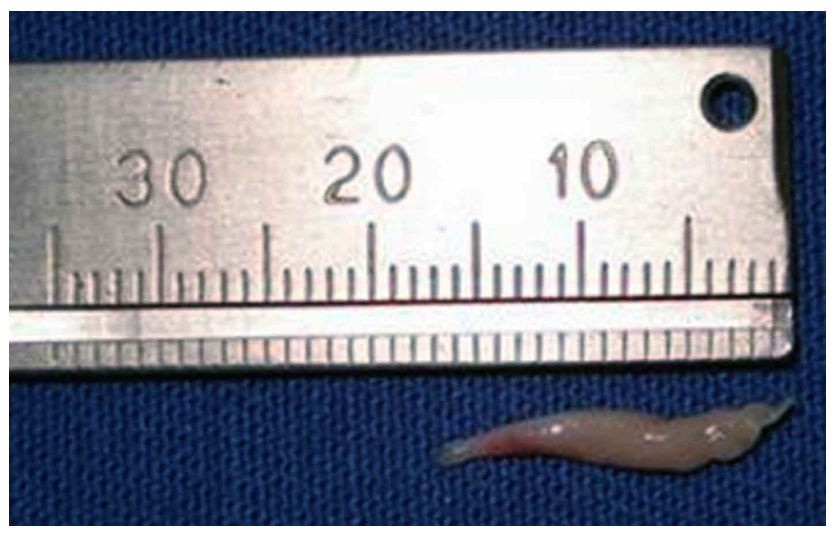

Fig. 2. Mummified pulp tissue removed.

\section{DISCUSSION}

Intrusive luxation is one of the most severe forms of traumatic injuries in which the affected tooth is forced to displace deeper into the alveolus as shown in the present paper (Güngör et al., 2006). The treatment of intrusive luxation injuries is still widely discussed in the literature (Luna et al., 2008). 


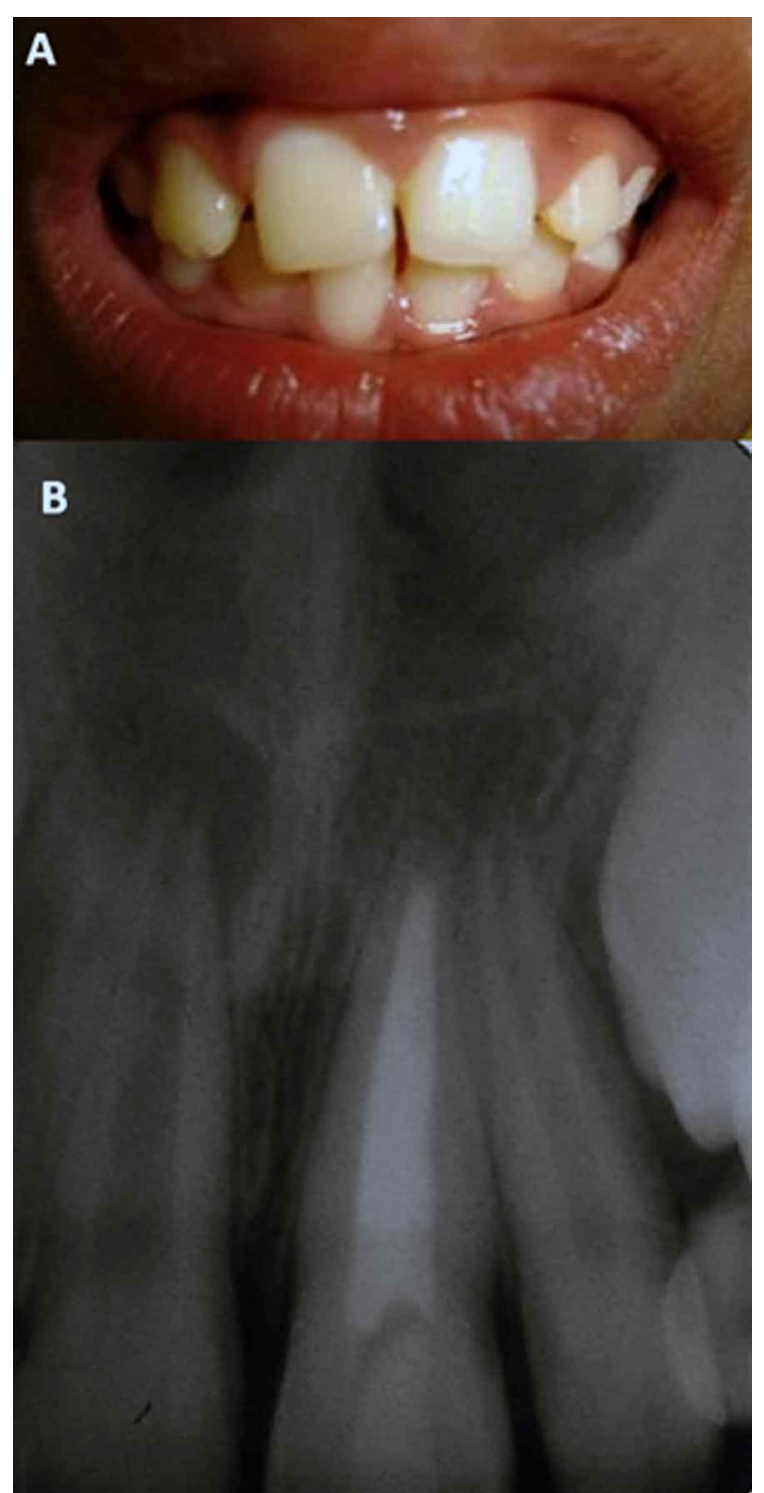

Fig. 3. A) Clinical appearance of the intruded tooth after orthodontic treatment; B) A radiograph which was taken 5 years after the initial trauma, and in which pulp canal obliteration of the intruded tooth can be clearly seen.

Damage to the bud of the permanent tooth is related to the direction and intensity of impact, the position taken over by the intruded tooth, the type of treatment and by the stage of bud formation at the moment of the trauma. The most severe form of luxation injury, intrusion, not surprisingly, yields the poorest prognosis and requires more complex treatment (Güngör et al.).

The diagnosis of the intrusion can be carried out clinically by digital palpation of the vestibule of the labial bone plate however, it is essential that a radiograph be taken to confirm the exact position. This is especially necessary when no part of the tooth is visible in the oral cavity and may be misinterpreted as avulsion. Besides confirming the new position of the tooth, the radiograph shows the direction of the displacement and whether the intruded tooth has invaded the follicle of the permanent tooth or not (Güngör et al.).

Treatment alternatives for an impacted central incisor include extraction and restoration with a bridge or an implant later when growth has ceased; extraction and closure of the space by substituting the lateral incisor for the central incisor with subsequent prosthetic restoration; and surgical exposure, orthodontic space opening, and traction of the impacted central incisor into its proper position. Clinicians should consider treatment goals that minimize injuries to the dentition and the periodontium (Frank, 2000).

In this specific case, treatment was based on the presented in the worldwide literature as suggested for intruded permanent teeth: extrusion with orthodontic device and long term follow up (Andreasen et al., 2006a).

Several complications have been described as a consequence of traumatic injuries, including coronal discoloration, obliteration of the pulp canal, pulpal necrosis, pathologic root resorption and ankylosis (Calasans-Maia et al.). When a dental trauma occurs, a series of injuries may occur to different types of cells, not just to the teeth themselves but also in adjacent tissues, among which there is physiological interaction (Torriani et al., 2008), such as the reported mummification case.

Pulp tissue, as other tissues in the human body, tends to change with traumas. Some of those changes are natural while others occur as result of injuries to the dentin-pulp complex such as caries lesions, periodontal disease, calcifications, as in the present report, or restorative dental procedures. Normally conducted endodontic treatment must take place to obtain maximal results, but only after the restabilization of the tooth.

PUPO, J. A. C.; ROSSI, A. C.; FREIRE, A. R.; CARIA, P. H. F. \& PRADO, F. B. Extrusión ortodóncica del incisivo central superior: un caso raro de momificación pulpar. Int. J. Odontostomat., 7(2):241-244, 2013.

RESUMEN: Debido a su localización anatómica, los incisivos centrales superiores son los dientes más afectados cuando se refieren a las lesiones traumáticas de la región craneofacial, entre los traumas nasales. En la infancia, lesión traumática suele ser 
ocasionado por accidentes de bicicleta, deportes, actividades recreativas o caídas. El objetivo de este artículo es describir un tratamiento para la intrusión del incisivo central superior izquierdo y las complicaciones posteriores en un niño de 8 años de edad. Asimismo, el informe hace hincapié en la importancia de cuidado a largo plazo con un seguimiento intrusión dientes permanentes. Tejido de la pulpa, como otros tejidos en el cuerpo humano, tiende a cambiar con traumas. Algunos de estos cambios son naturales, mientras que otros se producen como consecuencia de las lesiones del complejo dentina-pulpa, como las lesiones de caries, enfermedad periodontal, calcificaciones, como en el presente informe, restauración o intervención dental. Tratamiento endodóntico a cabo normalmente deben tener lugar para obtener los máximos resultados, pero sólo después de la re-estabilización del diente.

PALABRAS CLAVE: ortodoncia extrusión, calcificación pulpar, movimiento dental, avulsión dental.

\section{REFERENCES}

Andreasen, J. O. Etiology and pathogenesis of traumatic dental injuries. A clinical study of 1,298 cases. Scand. J. Dent. Res., 78(4):329-42, 1970.

Andreasen, J. O.; Bakland, L. K. \& Andreasen, F. M. Traumatic intrusion of permanent teeth. Part 2. A clinical study of the effect of preinjury and injury factors, such as sex, age, stage of root development, tooth location, and extent of injury including number of intruded teeth on 140 intruded permanent teeth. Dent. Traumatol., 22(2):90-8, 2006a.

Andreasen, J. O.; Bakland, L. K.; Matras, R. C. \& Andreasen, F. M. Traumatic intrusion of permanent teeth. Part 1. An epidemiological study of 216 intruded permanent teeth. Dent. Traumatol., 22(2):83-9, 2006b.

Andreasen, F. M. \& Pedersen, B. V. Prognosis of luxated permanent teeth - the development of pulp necrosis. Endod. Dent. Traumatol., 1(6):207-20, 1985.

Calasans-Maia, Jde A.; Calasans-Maia, M. D.; da Matta, E. N. \& Ruellas, A. C. Orthodontic movement in traumatically intruded teeth: a case report. Dent. Traumatol., 19(5):2925, 2003.

Caliskan, M. K.; Cinsar, A.; Türkün, M. \& Akkemik, Ö. Delayed endodontic and orthodontic treatment of cross-bite occurring after luxation injury in permanent incisor teeth. Endod. Dent. Traumatol., 13(6):292-6, 1997.

Chaushu, S.; Shapira, J.; Heling, I. \& Becker, A. Emergency orthodontic treatment after the traumatic intrusive luxation of maxillary incisors. Am. J. Orthod. Dentfac. Orthop., 126(2):162-72, 2004.
Frank, C. A. Treatment options for impacted teeth. J. Am. Dent. Assoc., 131(5):623-32, 2000.

Güngör, H. C.; Cengiz, S. B. \& Altay, N. Immediate surgical repositioning following intrusive luxation: a case report and review of the literature. Dent. Traumatol., 22(6):3404, 2006.

Kokich, V. G.; Nappen, D. L. \& Shapiro, P. A. Gingival contour and clinical crown length: their effect on the esthetic appearance of maxillary anterior teeth. Am. J. Orthod., 86(2):89-94, 1984.

Luna, A. H.; Moreira, R. W. \& de Moraes, M. Traumatic Intrusion of Maxillary permanent incisors into the nasal cavity: report of a case. Dent. Traumatol., 24(2):244-7, 2008.

Oulis, C.; Vadiakas, G. \& Siskos, G. Management of intrusive luxation injuries. Endod. Dent. Traumatol., 12(3):113-9, 1996.

Taintor, J. F.; Bonness, P. W. \& Biesterfeld, R. D. The intruded tooth. Dent. Surv., 55(6):30-4, 1977.

Torriani, D. D.; Bonow, M. L.; Fleishmann, M. D.; \& Müller, L. T. Traumatic Intrusion of primary tooth: follow up until eruption of permanent successor tooth. Dent. Traumatol., 24(2):235-8, 2008.

Correspondence to:

Ana Cláudia Rossi

Department of Morphology, Piracicaba Dental School

State University of Campinas - UNICAMP.

901, Limeira Ave. - P.O. Box \#52

Piracicaba

São Paulo

BRAZIL

Email: anaanatomia@gmail.com

Received: 12-09-2012

Accepted: 29-05-2013 